\title{
Monitoring Food Additives and Nutritional Composition of Labels of Food Bases
}

\author{
Stela-Gabriela JELEA ${ }^{1 *}$, Marian JELEA ${ }^{1}$, Lucia MIHALESCU ${ }^{1}$, Zorica VOȘGAN ${ }^{1}$, Oana-Corina JELEA ${ }^{2}$ \\ ${ }^{1}$ Faculty of Science, North University Center at Baia Mare, Technical University of Cluj-Napoca, Victoriei \\ Street, No.76, 430122, Baia Mare, Romania; \\ ${ }^{2}$ Faculty of Environmental Science and Engineering, University Babeș-Bolyai, Fântânele Street, No.30, \\ 400294, Cluj-Napoca, Romania; \\ *corresponding author: stela.jelea@cunbm.utcluj.ro
}

Bulletin UASVM series Agriculture 76(1) / 2019

Print ISSN 1843-5246; Electronic ISSN 1843-5386

DOI:10.15835/buasvmcn-agr: 2018.0007

\begin{abstract}
During June, 2017, ten products from the food bases category have been studied. The companies and the products types were noted and the manufacturer's labels were studied. It has been found that the rules on the labeling of food bases are respected. The study had the following objectives: studying the ingredients and the nutritional composition and identifying the additives used in the manufacture of the product. Studying product labels also highlighted an increased salt and sugar content. The percentage of dehydrated vegetables was between $4.49 \%$ and $38 \%$. The vegetables content was different for the food bases investigated. The $40 \%$ of food bases had between nine and ten dehydrated vegetables, the $60 \%$ had between four and six dehydrated vegetables. Additives added to foods during processing are important to improve their appearance and to extend their shelf life.
\end{abstract}

Keywords: composition content, food bases, labels, nutritional content

\section{Introduction}

The food bases labels are one source of information for consumers. Labels assist the consumers in determining the nutritional value and ingredients of foods. According to Regulation $1169 / 2011$ of the European Parliament and of the Council of 25 October 2011, prepackaged products must contain complete information in order to allow consumers to make informed choices (Grunert and Willis, 2007; Campos et al., 2011; Mhurchu et al., 2018).

There are a variety of food bases on supermarket shelves. They contain vegetables, greeneries, spices and food additives. In order to evaluate the quality of a mixture, the label with compositional and nutritional information should be read. The compositional label provides data on ingredients and additives used in the product in descending order. The quality of ingredients and flavors are responsible for the sensory and nutritional quality of the product (Mencinicopschi, 2010).

Today, more than 3,000 substances are used as food additives by national and international manufacturers (Wilson and Bahna, 2005). Additives added to food bases are used to improve their appearance and to extend their shelf life (Jacotot and Le Parco, 2000; Saltmarsh, 2013). They do not provide any nutritional benefit to the consumer. Some of these additives have been shown to have harmful effects on the consumer's body. Public health specialists have made a list of acceptable and recognized additives that are safe to use and a list of toxic additives (Drichoutis et al., 2005; Miller and Cassady, 2015).

The nutritional label affects the behavior of consumers because they want to avoid the adverse nutrients in food products. 
Table 1. The salt content, the percentage of vegetables and the ingredients list of studied products

\begin{tabular}{|c|c|c|c|c|}
\hline No. & Products & $\begin{array}{c}\text { Salt } \\
(\mathrm{g} / 100 \mathrm{~g})\end{array}$ & $\begin{array}{l}\text { Vegetables } \\
\text { content }(\%)\end{array}$ & Ingredients list \\
\hline 1 & $\begin{array}{l}\text { DELIKAT vegetables } \\
\text { tastefully }\end{array}$ & 62.0 & 10.45 & $\begin{array}{c}\text { Carrot } 6.1 \% \text {, red pepper } 1 \% \text {, onion } 0.4 \% \text {, mashed } \\
\text { tomato powder } 0.05 \% \text {, parsley root } 0.7 \% \text {, garlic } \\
0.3 \% \text {, leek, vegetable juice - nap }\end{array}$ \\
\hline & DELIKAT vegetables flavor & & & Carrot $12 \%$, red pepper powder $0.2 \%$, onion \\
\hline 2 & ball & 52.3 & 15.00 & $\begin{array}{l}\text { 0.6\%, mashed tomato powder, parsnip, garlic, } \\
\text { leek, spinach powder, red beet powder }\end{array}$ \\
\hline 3 & VEGIMIX food bases & 76.0 & 8.50 & Carrot, parsnip, onion, parsley \\
\hline 4 & $\begin{array}{l}\text { ROLLTON chicken - taste } \\
\text { food bases }\end{array}$ & 65.7 & 4.49 & $\begin{array}{c}\text { Carrot } 3.86 \% \text {, parsnip, parsley } 0.5 \% \text {, dill } 0.13 \% \\
\text { dehydrated chicken } 0,1 \%\end{array}$ \\
\hline 5 & $\begin{array}{l}\text { VEGETA food supplement } \\
\text { Podravska }\end{array}$ & 56.9 & 15.50 & Carrot, pastry, potato, onion, celery, parsley leaves \\
\hline 6 & VEGETA richness of taste & 56.9 & 15.50 & $\begin{array}{c}\text { Carrot, parsnip, potato, onion, celery, parsley } \\
\text { leaves }\end{array}$ \\
\hline 7 & $\begin{array}{l}\text { VEGETA NATURELLA with } \\
\text { no added universal food } \\
\text { additives }\end{array}$ & 54.8 & 30.00 & $\begin{array}{c}\text { Carrot, onion, parsnip, potato, celery, leek, pepper, } \\
\text { garlic, parsley leave }\end{array}$ \\
\hline 8 & MIRODENIA food bases & 52.0 & 38.00 & $\begin{array}{c}\text { Carrot } 18-23 \% \text {, onion, } 6-10 \% \text {, parsnip } 2.5 \% \text {, leek } \\
2-5 \% \text {, parsley } 1-4 \% \text {, cauliflower } 0.5-1 \%\end{array}$ \\
\hline 9 & $\begin{array}{l}\text { MIXTURE of vegetables the } \\
\text { secret of the chef }\end{array}$ & 85.0 & 12.00 & Carrot, parsnip, potato, onion, parsley, onion \\
\hline 10 & $\begin{array}{l}\text { MAGGI vegetables - taste } \\
\text { secret }\end{array}$ & 66.5 & 7.20 & $\begin{array}{l}\text { Carrot, leek powder, garlic powder, onion and } \\
\text { onion powder, parsley leaves, spinach powder, } \\
\text { tomato, parsnip, celery powder, red pepper }\end{array}$ \\
\hline
\end{tabular}

The research aimed to study the composition and nutritive information from labels of some food bases.

\section{Materials and Methods}

During June 2017, ten spice-type condiments were purchased. The products were randomly selected. The following food bases have been studied: Delikat vegetables tastefully, Delikat vegetables flavor ball, Vegimix food bases, Rollton chicken - taste food bases, Vegeta food supplement Podravska, Vegeta richness of taste, Vegeta Naturella with no added universal food additives, Mirodenia food bases, Mixture of vegetables the secret of the chef and Maggi vegetables - taste secret.

The study had the objectives of studying the: ingredients used; percentage of dehydrated vegetables products; nutritional composition; caloric value and the content of the food additives.

\section{Results and Discussions}

The list of ingredients contains important product quality data. The Food and Drug Administration (2014) recommends that labels comply with certain requirements to enable consumers to be properly informed.

The first ingredient on the ingredients list was iodized salt. The salt content of the studied products ranged between $52.3 \mathrm{~g}$ and $85 \mathrm{~g}$ from $100 \mathrm{~g}$. The Mirodenia food bases had the smallest amount of $52 \mathrm{~g}$ of salt from $100 \mathrm{~g}$. The Mixture of vegetables the secret of the chef had $85 \mathrm{~g}$ of salt from $100 \mathrm{~g}$. Vegimix - food bases and Maggie vegetables - taste secret had an increased salt content of $76 \mathrm{~g} / 100 \mathrm{~g}$ and $66.5 \mathrm{~g} / 100 \mathrm{~g}$ (Tab. 1).

High sodium intake increases blood pressure (Chrysant, 2016) and represents a risk factor for cardiovascular diseases (He and MacGregor, 2013; Chrysant, 2016). Reduction of salt intake in the population can be achieved by gradually reducing the amount of salt added to food ( $\mathrm{He}$ and MacGregor, 2013). The World Health Organization $(2003,2004)$ recommends a daily consumption of no more than $5 \mathrm{~g}$ of salt.

The ingredient lists provided us information about the percentage of dehydrated vegetables. It ranged between $4.49 \%$ and $38 \%$. Vegeta Naturella and Mirodenia had a high percentage of dehydrated vegetables (30\% and 38\%). The Rollton product had the lowest percentage of dehydrated 
Table 2. The nutritional composition of the investigated products

\begin{tabular}{ccccccc}
\hline Products & $\mathrm{F}$ & \multirow{2}{*}{$\mathrm{AGS}(\mathrm{g})$} & $\begin{array}{c}\mathrm{C} \\
(\mathrm{g})\end{array}$ & $\begin{array}{c}\mathrm{S} \\
(\mathrm{g})\end{array}$ & $\begin{array}{c}\mathrm{P} \\
(\mathrm{g})\end{array}$ & $\begin{array}{c}\mathrm{F} \\
(\mathrm{g})\end{array}$ \\
\hline DELIKAT vegetables tastefully & 0.80 & 0.20 & 22.00 & 21.00 & 7.00 & 3.50 \\
\hline DELIKAT vegetables flavor ball & 1.20 & 0.30 & 28.00 & 18.00 & 5.80 & 4.10 \\
\hline VEGIMIX food bases & 0.12 & 0.02 & 18.25 & 15.14 & 0.71 & - \\
\hline ROLLTON chicken - taste food bases & 0.70 & 0.20 & 14.80 & 11.60 & 1.00 & 0.70 \\
\hline VEGETA food supplement Podravska & 0.40 & 0.20 & 32.00 & 22.00 & 8.50 & - \\
\hline VEGETA richness of taste & 0.50 & 0.20 & 32.00 & 22.00 & 8.50 & - \\
\hline VEGETA NATURELLA & 0.90 & 0.50 & 28.00 & 23.00 & 4.40 & - \\
\hline MIRODENIA food bases & 2.00 & 0.30 & 22.30 & 20.40 & 4.60 & 10.60 \\
\hline MIXTURE of vegetables the secret of the chef & 0.45 & - & 27.48 & - & 8.25 & - \\
\hline MAGGI vegetables - taste secret & 1.80 & 0.20 & 20.8 & 11.40 & 5.80 & 2.10 \\
\hline Note:F- fats (g/100g); AGS - saturated fatty acids (g/100g); - carbohydrates $(\mathrm{g} / 100 \mathrm{~g}) ; \mathrm{S}-$ sugar (g/100g),P-proteins (g/100g); F- fibers
\end{tabular}
(g/100g).

vegetables (4.49\%). The investigated products had between two and ten dehydrated vegetables. Vegeta products had in their composition: carrot, parsnip, onion, celery, leek, pepper, parsley leaves and potato. The potato present in the composition determines the increase in the carbohydrates content and the energy value of the product.

Maggi products contains: carrot, leek powder, garlic powder, onion and onion powder, spinach powder, tomato, parsley leaves, parsnip, red pepper and celery powder. The food bases Vegeta and Maggi contain celery. Celery has a potent antimicrobial activity against Bacillus subtilis, Escherichia coli and Saccharomyces cerevisiae (De et al., 1999).

The energy value of basal spices for food is determined by calorigenic trophies (lipids, carbohydrates, proteins). The energy value of the products surveyed ranged from $164 \mathrm{kcal} / 100 \mathrm{~g}$ (Vegeta - Podravska and Vegeta - richness of taste) and $71 \mathrm{kcal} / 100 \mathrm{~g}$ (Rollton).

Thestudy evaluated thenutritional information from labels content of food bases (Tab. 2). The nutritional label shows the nutrient content of 100 $\mathrm{g}$ of the product. Nutrition knowledge is important for the choice of food bases. The fats content of the food bases investigated was between $0.12 \mathrm{~g}$ and $2 \mathrm{~g}$ from $100 \mathrm{~g}$ (Mirodenia - $2 \mathrm{~g}$; Maggie - $1.8 \mathrm{~g}$; Vegimix - $0.12 \mathrm{~g}$ ). Vegimix had low fats content but also a low percentage of dehydrated vegetables $(8.5 \%)$.

The content of saturated fatty acids ranged between $0.02 \mathrm{~g}$ and $0.3 \mathrm{~g}$ of $100 \mathrm{~g}$. Vegetables are considered healthy foods because they are low in fats but very high in fibers and other nutrients. The fibers content of $100 \mathrm{~g}$ was between $10.60 \mathrm{~g}$
(Mirodenia) and $0.70 \mathrm{~g}$ (Rollton). The nutritional labels from Vegeta products do not contain information about fibers content.

Producers have the obligation to display the nutritional values of the products, specifying the proportion of carbohydrates derived from sugars. The carbohydrates content of $100 \mathrm{~g}$ of product ranged from $32 \mathrm{~g}$ (Vegeta Podravska and Vegeta taste richness) and $14.80 \mathrm{~g}$ (Rollton). Delikat vegetable flavor ball and Vegeta Naturella had 28 $\mathrm{g}$ of carbohydrates of $100 \mathrm{~g}$. Vegeta products have potatoes, which are responsible for increasing the carbohydrates content.

Nutritional values provide information about the total amount of sugar the product contains from all sources. In the food industry, sugar is added to improve the taste of food and its shelf life. Sugar added to the food bases had different names as dextrose or maltodextrin. The amount of sugar in $100 \mathrm{~g}$ was between $11.4 \mathrm{~g}$ and $23 \mathrm{~g}$.

Increased amounts of sugar have been found in the following products: Vegeta Naturella (23 $\mathrm{g} / 100 \mathrm{~g})$; Delikat vegetables tastefully $(21 \mathrm{~g} / 100$ g) and Mirodenia (20.40 g/100 g). Maggie had the smallest amount of sugar $(11.4 \mathrm{~g} / 100 \mathrm{~g})$. The World Health Organization (2003) recommends not exceeding $50 \mathrm{~g}$ of sugar per day for adults.

The flavors used in the investigated products are natural. In the category of aromatics were used celery seeds (Vegimix and Mirodenia), celery and curcumin seeds (Delikat vegetables), curcumin (Mixture of vegetables), black pepper, curcumin, dill (Vegeta Naturella), black pepper and turmeric (Maggi).

The use of food additives natural or synthetic origins in food is well regulated by European and 
Table 3. The contents of the additives added to food bases

\begin{tabular}{ccc}
\hline No. & Products & List of flavor enhancers \\
\hline \multirow{2}{*}{1} & DELIKAT vegetables tastefully & E621 - monosodium glutamate \\
& E627 - disodium 5' guanylate \\
& E631 - disodium inosinate \\
\hline \multirow{2}{*}{ DELIKAT vegetables flavor ball } & E621 - monosodium glutamate \\
& & E627 - disodium 5' guanylate \\
& E631 - disodium inosinate \\
\hline 3 & VEGIMIX food bases & Does not have \\
\hline \multirow{2}{*}{ ROLLTON chicken - taste food bases } & E621 - monosodium glutamate \\
& E627 - disodium 5' guanylate \\
& V6631 - disodium inosinate \\
\hline 5 & PEG food supplement & E621 - monosodium glutamate \\
\hline 6 & VEGETA richness of taste & E631 - disodium inosinate \\
\hline 7 & VEGETA NATURELLA & E631 - disodium inosinate \\
\hline 9 & MIRODENIA food bases & Does not have \\
\hline 10 & MIXTURE of vegetables & Does not have \\
& MAGGI vegetables - taste secret & E621 - monosodium glutamate \\
\hline
\end{tabular}

national authorities. The European Economic Community, in 1988, introduced the regulation of labeling and numbering of food additives, flavors, taste enhancers and preservatives, to promote a fair market and a safe food product in the European Community (CEC 2011; Haen, 2014).

Consumers have the right to make an informed choice about the food they consume and most additives are required to be declared on the food ingredient labels as part of the ingredient list (Saltmarsh, 2013; Al-Harthy et al. 2017).

The food additives used in these products have been the flavor and taste enhancers. Four flavor enhancers have been identified: E621 monosodium glutamate; E627 - disodium 5' guanylate; E631 - disodium inosinate and E635 - disodium 5' ribonucleotides (Tab. 3). The flavor enhancers used are approved by the Codex Alimentarius Commission, FAO/WHO, 1992.

Out of the products investigated, 30\% had three flavor enhancers (monosodium glutamate, disodium inosinate and disodium guanylate), 30\% two flavor enhancers (monosodium glutamate and disodium inosinate or disodium 5 ' ribonucleotides) and $10 \%$ monosodium glutamate. Vegeta Naturella, Mirodenia and Vegimix do not contain flavor enhancers. Vegimix had silicon dioxide in the composition. It is an anti-agglomerating agent and it is used as a carrier.
Monosodium glutamate (MSG), a common flavor enhancer found in various canned foods. MSG has no texture or smell of its own, and therefore serves to emphasize the natural flavor (Singh, 2005).

Pandey and Upadhyay (2012) suggested that MSG accelerating Huntington's, Alzheimer's and Parkinson's disease, causes cancer, increases hyperactivity, DNA damage, and fetal abnormalities in animals. MSG has been also suspected to induce a neurotoxic effect on the nervous system (Quines et al., 2014 after Al-Harthy et al., 2017), trigger asthma (Yoneda et al. 2011 after Al-Harthy et al., 2017), and liver injury (Nakanishi et al. 2008 after Al-Harthy et al., 2017).

The consumers with monosodium glutamate intolerance can develop a complex of symptoms that are characterized by: chest pain, headache, nausea, drowsiness, bronchospasm (difficulty breathing) asthma (Scopp, 1991; Jennifer et al., 2009; Pandey and Upadhyay, 2012).

Specialty literature (Khodjaeva et al. 2013) provided us information that disodium inosinate (E631) may cause gout. Disodium 5' ribonucleotide (E635) is used to enhance the taste of some products. May be associated with itchy skin rashes up to 30 hours after ingestion, rashes may vary from easy form to dramatic form (Khodjaeva et al. 
2013). The reaction is dose-related and cumulative some individuals are more sensitive than others.

Riboflavin (E101) was present in $80 \%$ of the investigated products. FAO/WHO rules allow the use of riboflavin in condiments or food bases. The adverse effects of flavor enhancers depend on the amount consumed.

Ingredients are indicated in descending order of their quantity. The first ingredient indicated on labels of food bases was iodine salt (100\%). The second ingredient was dehydrated vegetables $(60 \%)$, sugar $(20 \%)$ and flavor enhancers $(20 \%)$. The third ingredient was flavor enhancers (30\%), sugar $(40 \%)$, dehydrated vegetables $(10 \%)$, garlic $(10 \%)$ and spices $(10 \%)$.

Consumers should read carefully the information from labels about compositional and nutritional value of the food bases to choose the product that meets the conditions expected.

\section{Conclusion}

The compositional study of the food bases revealed an increased salt content. The dehydrated vegetables content was different in the investigated products. The Vegeta Naturella and Mirodenia products had an increased content of dehydrated vegetables. Delikat vegetables flavor ball and Maggi vegetables - taste secret are among the products with an increased number of dehydrated vegetables (nine or ten). Food bases Vegimixt and Rollton have low contents of dehydrated vegetables. Consumers must carefully read the composition labels to choose the basis products for foods containing an increased percentage of dehydrated vegetables.

The ingredient lists from labels provides important information that can contribute to evaluate the food bases. Some food bases are nutritionally unbalanced because of their high salt and sugar contents and low content of dehydrated vegetables. In the investigated products were observed four flavor enhancers: E621 - monosodium glutamate; E627 - disodium 5'- guanylate; E631 - disodium inosinate; E635 - disodium 5 ,ribonucleotides. The $70 \%$ of the investigated products showed between one and three flavor enhancers. Vegeta Naturella and Mirodenia did not have the addition flavors.

The study of the compositional and nutritional labels is necessary to choose a correct food bases.

\section{References}

1. Al-Harthy AM, Harib A, Al-Shaaibi AJ, Al-Toubi SS, AbuKhader MM (2017). Food additives content in selected snack foods and beverages and public perception of E-numbers in Muscat, Oman. Ath. J. Health, 4(1): 83-95.

2. Campos S, Doxey J, Hammond D (2011). Nutrition labels on pre-packaged foods: A systematic review. Public Health Nutr. 14:1496-1506. Doi: 10.1017/S1368980010003290.

3. Chrysant SG (2016). Effects of high salt intake on blood pressure and cardiovascular disease: the role of COX inhibitors. Clin. Cardiol. 39(4): 240-242. Doi: 10.1002/ clc.22536. doi.org/10.1002/clc.22536.

4. Commission of the European Communities (2011). Report from the commission to consumer information on foodstuffs in the European Union. The official web site of the European Union, Brussels, EU. Retrieved from http:// eur-lex.europa.eu/legal-content/RO/ALL/.

5. Codex Alimentarius. International food standards. General standard for food additives codex stan 1931995. Retrieved from http://www.fao.org/fao-whocodexalimentarius/sh-proxy/en/.

6. De M, De KA, Banerjee AB (1999). Antimicrobial screening of some Indian spices. Phytother. Res. 13(7): 616-618. Doi. org/10.1002/(SICI)1099-1573(199911)13:7\%3C616:

7. AID-PTR475\%3E3.0.CO; 2-V.

8. Drichoutis AC, Lazaridis P, Nayga RM (2005). Knowledge and consume use of nutritional food labels. Eur. Rev. of Agr. Econom., 32(1): 93-118. Doi.org/10.1093/erae/jbi003.

9. Food and Drug Administration (2014). Food Labeling, Food: designation of ingredients. 21 C.F.R. $§ 101.4$.

10. Grunert KG, Wills JM (2007). A review of European research on consumer response to nutrition information on food labels. J. Public Health 15 (5): 385-399. Doi 10.1007/s10389-007-0101-9.

11. Haen D. (2014). The paradox of E-Numbers: Ethical, Aesthetic, and Cultural Concerns in the Dutch Discourse on Food Additives. J. Agr. Environ. Ethics 27(1): 27-42. Doi: $10.1007 / \mathrm{s} 10806-013-9440-4$.

12. He FJ, MacGregor GA (2013). Effect of longer-term modest salt reduction on blood pressure. Cochrane Database Syst. Rev. 4: CD004937. Doi: 10.1002/14651858.CD004937.

13. Jacotot B, Le Parco JC (2000). Nutrition et alimentation. $2^{\mathrm{e}}$ edition, Ed. Masson, Paris.

14. Khodjaeva U, Bojňanská T Vietoris V, Sytar O, Singh R (2013). Food Additives as Important Part of Functional Food. Int. Res. J. Biological Sci., 2(4): 1-6. ISSN 2278-3202.

15. Mencinicopschi G (2010). Şi noi ce mai mâncăm. Vol. 1. Coreus Publishing, pp. 168-189.

16. Pandey RM, Upadhyay SK (2012). Food Additive Division of Genetics. Plant breeding \& Agrotechnology, National Botanical Research Institute, Lucknow, India. Doi: 10.5772/34455.

17. Scopp AL (1991). MSG and hydrolyzed vegetable protein induced headache: review and case studies. Headache, 31(2):107-110. PMID: 2030071. 
18. Singh M, (2005). Fact or fiction? The MSG controversy. Haward Law School. https://dash.harvard.edu/ bitstream/handle/1/8846733/sing05.pdf?sequence=1.

19. Miller LM, Cassady DL (2015). Appetite. Sep. 1, 92: 207216. Doi: 10.1016/j.appet.2015.05.029.

20. Mhurchu CN, Eyles H, Jiang Y, Blakely T (2018). Do nutrition labels influence healthier food choices? Analysis of label viewing behaviour and subsequent food purchases in a labelling intervention trial Appetite 121: 360-365. https://doi.org/10.1016/j.appet.2017.11.105.

21. Saltmarsh M (2013). Essential guide to food additives. $4^{\text {th }}$ Ed.. The Royal Society of Chemistry Publishing, Cambridge, UK. eISBN:978-1-84973-498-1.

22. Wilson BG, Bahna SL (2005). Adverse reactions to food additives. Ann Allergy Asthma Immunol. 95(6): 499-507. Doi: 10.1016/S1081-1206(10)61010-1.
23. WHO Technical Report Series 916. (2003). Diet, Nutrition and the Prevention of Chronic Diseases. In WHO Technical Report Series 916, WHO: Geneva, Switzerland. http:// apps.who.int/iris/bitstream/10665/42665/1/WHO_ TRS_916.pdf.

24. World Health Organization (2004). Global Strategy on Diet, Physical Activity and Health, WHO: Geneva, Switzerland. Retrieved from http://www.who.int/ dietphysicalactivity/strategy/eb11344/strategy_english_ web.pdf.

25. Xion JS, Branigan D, Minghua L. (2009). Deciphering the MSG controversy. Int. J. Clin. Exp. Med. 2(4): 329-336. PMCID: PMC2802046. 